\title{
Social inequalities in health related behaviours in Barcelona
}

Carme Borrell, Felicitas Domínguez-Berjón, M Isabel Pasarín, Josep Ferrando, Izabella Rohlfs, Manel Nebot

\begin{abstract}
Objective-This study describes social class inequalities in health related behaviours (tobacco and alcohol consumption, physical activity) among a sample of general population over 14 years old in Barcelona.
\end{abstract}

Design-Cross sectional study (Barcelona Health Interview Survey).

Setting-Barcelona city (Spain).

Participants-A representative stratified sample of the non-institutionalised population resident in Barcelona was obtained. This study refers to the 4171 respondents aged over 14.

Data-Social class was obtained from a Spanish adaptation of the British Registrar General classification. In addition, sociodemographic variables such as family structure and employment status were used. As health related behaviours tobacco consumption, alcohol consumption, usual physical activity and leisure time physical activity were analysed. Age adjusted percentages were compared by social class. Multivariate analysis was performed using logistic regression models.

Main results-Women in the upper social classes were more likely to smoke, the adjusted odds ratio (OR) for social class $\mathrm{V}$ in reference to social class I was $0.36(95 \%$ confidence intervals $(95 \% \mathrm{CI}): 0.19,0.67)$, while the opposite occurred among men although it was not statistically significant in multivariate analysis. Smoking cessation was more likely among men in the higher classes (OR for class V $0.41,95 \% \mathrm{CI}$ : $0.18,0.90)$. Excessive alcohol consumption among men showed no differences between classes, while among women it was greater in the upper classes. Engaging in usual physical activity classified as "light or none" in men decreased with lowering social class (OR class IVa: 0.55 and OR class IVb: 0.47). Women of social classes IV and $V$ were less likely to have two or more health risk behaviours (OR for class V 0.33, 95\% CI: 0.18, 0.62).

Conclusion-Health damaging behaviours are differentially distributed among social classes in Barcelona. Health policies should take into account these inequalities.

(F Epidemiol Community Health 2000;54:24-30)

Dr C Borrell, Municipal Institute of Public Health, Pl Lesseps 1, 08023 Barcelona, Spain

Accepted for publication 24 May 1999
Health related behaviours are often thought of as "voluntary", but this is a rather superficial view. For example, smoking and alcohol consumption may be regarded less as personal habits than as cultural norms, determined by social pressures; or persons of low social classes may not have the time or energy to engage in leisure time physical activity. ${ }^{1}$ It is now widely accepted that health status and its determinants, including lifestyle and health related behaviours, are differentially distributed among social classes. ${ }^{2}$

The determinants of health behaviour are in general poorly understood. In some cases, like eating patterns or leisure time physical activity, access and availability might play a direct part, as eating "healthy" and practising sports are relatively expensive options. In this regard, it is also well known that lower class persons tend to perform less physical activity in their leisure time and more in their jobs. ${ }^{2}{ }^{3}$

In some other behaviours the picture can be even more complex, especially when we are dealing with legal addictive substances such as tobacco and alcohol. The case of smoking is remarkable, as it seems to have followed a diffusion model in most developed countries after the second world war, ${ }^{4}$ a pattern that is strongly related to socioeconomic factors. In this regard, the current prevalence of smokers in the USA and northern European countries is higher in the lower social classes. However, the pattern seems to be different in southern European countries, especially among women, where the higher classes smoke more. ${ }^{56}$ In a previous study in Barcelona we reported a decrease in smoking among upper classes men between 1983 and 1992, paralleled by an increase in smoking among lower class women. ${ }^{7}$ Alcohol consumption is related to the historical position of alcohol within the local economy and social events. Nevertheless, some differences according to social class, with more heavy drinkers in disadvantaged classes, have been shown. ${ }^{12}$

Compared with other European countries, southern European countries present intermediate levels of wealth between those of north and central Europe and those of east Europe. In southern European countries the study of inequalities is relatively recent, and there are few studies available. ${ }^{8-10}$ The pattern of social inequalities in health in Spain, as in other countries of southern Europe, presents certain differential characteristics compared with central and northern European countries. ${ }^{10}{ }^{11}$

Barcelona, like most large cities, presents important social inequalities in health. So far, however, most studies have been based on mortality statistics, drawing attention to the higher mortality and shorter life expectancy in 
Table 1 Sample distribution by sociodemographic variables. Men and women aged over 14 years. Barcelona, 1992

\begin{tabular}{lll}
\hline & & \\
Sociodemographic variables & $\begin{array}{l}\text { Men } \\
\text { Number (\%) }\end{array}$ & $\begin{array}{l}\text { Women } \\
\text { Number (\%) }\end{array}$ \\
\hline Social class & & \\
I-Managerial, senior technical staff, free professionals. & $257(13.2)$ & $167(7.5)$ \\
II-Intermediate occupations and manager in commerce. & $274(14.1)$ & $319(14.3)$ \\
III-Skilled non manual workers. & $457(23.5)$ & $506(22.7)$ \\
IVa-Skilled manual workers. & $522(26.9)$ & $649(29.1)$ \\
IVb-Partly skilled manual workers. & $205(10.6)$ & $199(8.9)$ \\
V-Unskilled manual workers. & $64(3.3)$ & $189(8.5)$ \\
Missing data & $164(8.4)$ & $200(8.9)$ \\
Age group & & \\
15-24 & $372(19.2)$ & $378(17.0)$ \\
25-44 & $656(33.8)$ & $671(30.1)$ \\
45-64 & $554(28.5)$ & $701(31.4)$ \\
765 & $359(18.5)$ & $479(21.5)$ \\
Family structure & & \\
Live alone or alone with children & $163(8.4)$ & $417(18.7)$ \\
Couple, or couple and others & $1202(61.9)$ & $1251(56.1)$ \\
Parents or parents and others & $478(24.6)$ & $390(17.5)$ \\
Persons over 60 with children, or children and grandchildren & $7(0.3)$ & $33(1.5)$ \\
Others & $92(4.8)$ & $137(6.2)$ \\
Employment status & & \\
Worker & $1070(55.0)$ & $621(27.8)$ \\
Housewife & - & $902(40.4)$ \\
Unemployed & $152(7.8)$ & $125(5.6)$ \\
Student & $233(12.0)$ & $249(11.2)$ \\
Retired & $433(22.3)$ & $311(14.0)$ \\
Others & $52(2.7)$ & $20(0.9)$ \\
Missing data & $2(0.1)$ & $2(0.1)$ \\
Total & $1942(100)$ & $2229(100)$ \\
\hline & & \\
\hline & &
\end{tabular}

wards with lower socioeconomic levels, ${ }^{12-14}$ inequalities that have widened with time..$^{15}$ This study describes social class inequalities in health related behaviours (tobacco and alcohol consumption, physical activity) in the over 14 year population in the city of Barcelona.

\section{Methods}

The data analysed in this study were collected in 1992 in the Barcelona Health Interview Survey, a periodic cross sectional population survey carried out in the city of Barcelona (1 650000 inhabitants), in the north east of Spain. A representative stratified sample of the non-institutionalised population resident in Barcelona according to the population census of 1991 was obtained. The census tracks of the city were grouped into five strata, based on sociodemographic variables obtained from the 1986 census (variables based on age and sex distribution, educational level, occupational level, employment status and migration). The sample size in each stratum depended on the variability of sociodemographic variables in it. The sampling unit in each stratum was the individual and in each stratum a random sample of people was obtained. Total sample size was established as 5004 persons, with an alpha error of $5 \%$ and a maximum global error of $1.6 \%$ (this global error is one half the width of the desired sample confidence interval). ${ }^{16}$ The information was collected through a face to face interview carried out at home, between February 1992 and January 1993. Nonresponses were $9 \%$. This study refers to the 4171 respondents aged over 14 .

The questionnaire of the Barcelona Health Interview Survey was adapted from previous health interview surveys. ${ }^{16}$ The tobacco questions were based on WHO recommendations. ${ }^{17}$ The question on alcohol consumption was asked in the same way as it had been in the 1987 Health Interview Survey of the Basque
Country (Spain). ${ }^{18}$ Physical activity items were taken from those used in the Welsh Heart Health Survey in $1985 .^{19}$

Social class was obtained from a Spanish adaptation of the 1980 British Registrar General classification..$^{20}$ Class I includes managerial and senior technical staff and free professionals; class II includes intermediate occupations and managers in commerce; class III, skilled non-manual workers; class IV, skilled (IVa) and partly skilled (IVb) manual workers; and class V, unskilled manual workers. Social class was derived from current or last occupation. People reporting none were assigned the social class of the head of the household ( $22 \%$ of men and $44 \%$ of women).

The Spanish classification of social class was created by comparing the occupations in both Britain and Spain. In most cases occupations fell into the same social class, because it was assumed that the social position was the same. However, there were some cases assigned to a different social class. For example, writers and journalists in Spain were put in social class I. Non-manual occupations were assigned to social class III and manual to social class IV (whereas in the British classification both manual and non-manual skilled occupations are part of social class III). ${ }^{20}$ The Spanish classification has been widely used in Spain and has been recommended by the Spanish Epidemiological Society. ${ }^{21}$ Social class determined with this classification has shown a high correlation with educational level. ${ }^{22}$ Besides, family structure and employment status were used as other sociodemographic variables. ${ }^{23} 24$ Table 1 summarises characteristics of the population over 14 years of age, interviewed during the health survey, according to sociodemographic variables by men and women.

The variables studied were:

\section{TOBACCO CONSUMPTION}

People who smoked daily one or more cigarettes at the time of the survey were considered current smokers; those who had smoked one or more cigarettes a day in the past (six months ago or before) but did not smoke at the time of the survey were considered ex-smokers; and those who declared themselves non-smokers, or who smoked less than one a day were labelled non-smokers. The rate of smoking cessation was calculated as the number of ex-smokers over the total number of smokers and ex-smokers.

\section{ALCOHOL CONSUMPTION}

The amount of alcohol ingested daily, in grams, was determined by daily consumption during the previous week. The interviewees were classified as: non-drinkers, light drinkers (men who consumed less than $40 \mathrm{~g}$ per day and women who consumed less than $20 \mathrm{~g}$ ), and heavy drinkers (men who consumed $40 \mathrm{~g}$ or more per day, and women who stated they had consumed $20 \mathrm{~g}$ or more per day). The limits of alcohol for a heavy drinker reflect levels at which the risk of overall mortality increases. ${ }^{25}$ 
Table 2 Health related behaviours by social class. Age standardised percentages. Men and women aged over 14 years. Barcelona 1992

\begin{tabular}{|c|c|c|c|c|c|c|c|}
\hline & Sex & $\begin{array}{l}\text { Class I } \\
\% \%^{\star}(95 \% \text { CI })\end{array}$ & $\begin{array}{l}\text { Class II } \\
\%^{\star}(95 \% \text { CI })\end{array}$ & $\begin{array}{l}\text { Class III } \\
\%{ }^{\star}(95 \% \text { CI })\end{array}$ & $\begin{array}{l}\text { Class IVa } \\
\%{ }^{\star}(95 \% \mathrm{CI})\end{array}$ & $\begin{array}{l}\text { Class IVb } \\
\%{ }^{\star}(95 \% \mathrm{CI})\end{array}$ & $\begin{array}{l}\text { Class V } \\
\%{ }^{\star}(95 \% \text { CI })\end{array}$ \\
\hline \multicolumn{8}{|l|}{ Tobacco consumption } \\
\hline \multirow[t]{2}{*}{ Smoker } & M & $43.8(35.4,52.1)$ & $36.3(28.9,43.5)$ & $41.7(35.7,47.5)$ & $47.3(41.2,53.2)$ & $54.1(43.6,64.4)$ & $48.0(28.7,67.3)$ \\
\hline & $\mathrm{F}$ & $29.8(21.4,38.1)$ & $24.8(19.7,29.8)$ & $24.1(20.0,28.1)$ & $22.1(18.0,26.0)$ & $25.8(18.7,32.8)$ & $17.9(9.3,26.4)$ \\
\hline \multirow[t]{2}{*}{ Ex-smoker } & $M$ & $27.0(20.5,33.3)$ & $24.8(18.7,30.9)$ & $22.1(17.5,26.6)$ & $20.1(16.3,23.8)$ & $18.1(11.5,24.7)$ & $16.8(6.7,26.9)$ \\
\hline & $\mathrm{F}$ & $6.6(1.8,11.4)$ & $8.2(4.8,11.5)$ & $7.4(5.0,9.7)$ & $5.0(3.1,6.7)$ & $3.4(0.8,6.0)$ & $3.0(0.0,6.2)$ \\
\hline \multirow[t]{2}{*}{ Non-smoker } & $M$ & $29.2(22.5,35.9)$ & $38.9(31.3,46.3)$ & $36.2(30.8,41.7)$ & $32.6(27.6,37.5)$ & $27.8(20.4,35.1)$ & $35.1(18.5,51.7)$ \\
\hline & $\mathrm{F}$ & $63.6(48.7,78.37)$ & $66.8(56.6,77.0)$ & $68.5(60.5,76.3)$ & $73.0(66.4,79.4)$ & $70.8(59.0,82.5)$ & $79.1(65.3,92.8)$ \\
\hline \multicolumn{8}{|l|}{ Smoking cessation } \\
\hline & $\begin{array}{l}\mathrm{M} \\
\mathrm{F}\end{array}$ & $\begin{array}{l}36.3(27.5,45.0) \\
24.5(1.3,47.5)\end{array}$ & $\begin{array}{l}39.6(29.9,49.2) \\
38.7(14.5,62.9)\end{array}$ & $\begin{array}{l}31.3(24.8,37.7) \\
29.4(10.3,48.5)\end{array}$ & $\begin{array}{l}28.3(22.9,33.7) \\
29.0(14.1,43.9)\end{array}$ & $\begin{array}{l}23.8(15.1,32.6) \\
12.3(0.5,24.1)\end{array}$ & $\begin{array}{l}21.1(8.3,33.9) \\
23.5(0.0,47.5)\end{array}$ \\
\hline \multicolumn{8}{|l|}{ Alcohol consumption } \\
\hline \multirow[t]{2}{*}{ Non-drinker } & M & $27.0(20.5,33.5)$ & $29.1(22.5,35.6)$ & $29.7(24.6,34.8)$ & $30.2(25.5,34.8)$ & $32.7(24.3,41.2)$ & $41.8(22.9,60.5)$ \\
\hline & $\mathrm{F}$ & $45.6(33.2,57.9)$ & $47.9(39.2,56.4)$ & $45.3(38.9,51.5)$ & $57.8(51.8,63.6)$ & $64.1(52.9,75.1)$ & $71.9(57.7,85.8)$ \\
\hline \multirow[t]{2}{*}{ Light drinkers } & M & $61.3(51.6,71.0)$ & $59.6(50.2,68.8)$ & $62.0(54.8,69.2)$ & $57.1(50.5,63.7)$ & $55.1(44.6,65.6)$ & $45.2(27.3,63.1)$ \\
\hline & $\mathrm{F}$ & $44.0(32.9,55.1)$ & $42.6(35.2,50.0)$ & $49.5(43.1,55.9)$ & $36.2(31.4,41.0)$ & $31.4(23.4,39.3)$ & $25.7(17.3,34.2)$ \\
\hline \multirow[t]{2}{*}{$\begin{array}{l}\text { Excessive alcohol } \\
\text { consumption }\end{array}$} & M & $11.7(7.2,16.0)$ & $11.3(7.1,15.5)$ & $8.2(5.5,10.9)$ & $12.6(9.5,15.7)$ & $12.1(7.1,17.0)$ & $13.0(4.2,21.7)$ \\
\hline & $\mathrm{F}$ & $10.4(4.4,16.2)$ & $8.9(5.6,12.2)$ & $5.2(3.2,7.1)$ & $6.0(4.0,7.8)$ & $4.5(1.5,7.4)$ & $2.4(0.4,4.3)$ \\
\hline \multicolumn{8}{|l|}{ Usual physical activity } \\
\hline \multirow[t]{2}{*}{ Intense } & $\mathrm{M}$ & $4.1(1.4,6.8)$ & $5.5(2.6,8.3)$ & $5.1(3.0,7.1)$ & $19.3(15.4,23.2)$ & $15.6(10.2,20.9)$ & $11.5(0.0,23.0)$ \\
\hline & $\mathrm{F}$ & $3.6(0.1,6.9)$ & $6.3(3.2,9.2)$ & $2.9(1.3,4.3)$ & $4.4(2.6,6.0)$ & $8.7(4.5,12.8)$ & $8.6(3.9,13.2)$ \\
\hline \multirow[t]{2}{*}{ Moderate } & M & $41.0(33.0,49.0)$ & $42.1(34.2,50.0)$ & $49.8(43.2,56.3)$ & $40.2(34.7,45.5)$ & $47.5(37.3,57.6)$ & $29.8(16.0,43.51)$ \\
\hline & $\mathrm{F}$ & $49.6(37.2,61.9)$ & $52.6(43.9,61.3)$ & $55.5(48.5,62.4)$ & $53.6(47.8,59.3)$ & $55.9(45.4,66.3)$ & $57.2(44.3,70.1)$ \\
\hline \multirow[t]{2}{*}{ Light } & M & $12.7(8.2,17.2)$ & $13.2(8.7,17.6)$ & $9.6(6.8,12.4)$ & $14.9(11.5,18.3)$ & $17.3(11.5,23.0)$ & $19.5(8.1,30.84)$ \\
\hline & $\mathrm{F}$ & $19.5(10.9,28.1)$ & $20.3(15.2,25.3)$ & $15.9(12.1,19.5)$ & $22.5(18.7,26.2)$ & $19.0(12.8,25.2)$ & $18.5(11.5,25.4)$ \\
\hline \multirow[t]{2}{*}{ None } & $M$ & $41.1(33.1,48.9)$ & $39.1(31.6,46.6)$ & $35.0(29.5,40.4)$ & $25.1(20.7,29.3)$ & $19.6(13.1,26.0)$ & $39.1(21.8,56.4)$ \\
\hline & $\mathrm{F}$ & $27.3(18.7,35.8)$ & $20.7(15.1,26.1)$ & $25.5(21.0,30.0)$ & $19.2(15.8,22.5)$ & $15.9(10.4,21.4)$ & $15.4(9.4,21.3)$ \\
\hline \multicolumn{8}{|c|}{ Undertake no leisure time physical activity } \\
\hline & M & $74.4(63.6,85.1)$ & $74.0(63.6,84.4)$ & $77.1(68.9,85.3)$ & $77.5(69.8,85.0)$ & $81.6(68.4,94.7)$ & $79.5(55.5,100.0)$ \\
\hline & $\mathrm{F}$ & $86.3(69.6,100.0)$ & $79.5(68.8,90.2)$ & $84.6(76.0,93.1)$ & $83.6(76.4,90.7)$ & $84.5(71.7,97.3)$ & $86.1(71.2,100.0)$ \\
\hline
\end{tabular}

$\star \%$ : age standardised percentage.

USUAL PHYSICAL ACTIVITY

This variable was defined as the total physical activity usually undertaken and therefore includes activity on the job and outside it. It was obtained from a question in which the activity was catalogued as important or intense (physical activity requiring important physical effort), moderate (frequent walking), light (most of the day standing), or none (seated most of the day).

LEISURE TIME PHYSICAL ACTIVITY

Obtained from two questions that asked about the number of occasions on which the subject had performed various sports, for at least 20 minutes, of moderate intensity (bicycle riding, gymnastics, aerobics, jogging, tennis, swimming) and of high intensity (competition swimming, football, basketball, hockey, competition cycling, squash, martial arts). People who regularly and vigorously performed physical activity three or more times per week in leisure time were classified as having performed some leisure time physical activity, because it has been demonstrated that this amount of physical activity improves cardiovascular fitness. ${ }^{26}$

In the data analysis each person had an assigned weight to adjust for the sample stratification. To compare the different variables among the different social classes, we used age adjusted percentages by the direct method and its $95 \%$ confidence intervals $(95 \% \mathrm{CI}){ }^{27}$ The reference population was the whole survey sample ( $n=4171$ aged over 14). Multivariate analysis was performed to study the association between social class and health behaviours adjusting for age, employment status and family structure ${ }^{2324}$ through logistic regression models. Interaction between age and social class was tested in the models but it was not statistically significant. Goodness of fit was obtained using the Hosmer Lemeshow test. ${ }^{28}$

\section{Results}

In women the prevalence of smokers was higher in social class I (29.8\%) and decreased until social class V (18\%). The adjusted odds ratio (OR) for social class $\mathrm{V}$ in reference to social class I was 0.36 (95\%CI: $0.19,0.67)$. The opposite occurred among men, where the classes IV and V smoked more (table 2). These results were also reflected in the multivariate analyses adjusted for age, employment status and family structure, even though among men the association lost statistical significance (table 3). Smoking cessation was greater among men in the higher classes, OR for classes IV and $\mathrm{V}$ were less than 1 and statistically significant; in women no clear trends were observed (table 3).

Among women light and excessive alcohol consumption were greater in classes I and II, with ORs becoming progressively smaller and further from 1. Among men light alcohol consumption was more important in upper classes ( $61 \%$ of class I and $45 \%$ of class V, OR $=0.57$, $95 \% \mathrm{CI}: 0.32,1.00)$, while no differences were found in excessive alcohol consumption (tables 2 and 3$)$.

Less than $5 \%$ of men and women in class I declared that they usually performed intense physical activity in contrast with $11.5 \%$ of men and $8.6 \%$ of women in class $\mathrm{V}$ (table 2 ), an association that persisted in the multivariate analysis, the ORs for the lower classes being greater than 2 (table 3). People of social classes I and II were more likely to engage in usual physical activity classified as "light or none" than lower social classes (table 3). For leisure time physical activity the situation is reversed, particularly in men, as a greater proportion of the lower classes did not engage in physical activity three or more times per week (74\% of men in class I and $79 \%$ in class V). In the 
Table 3 Multivariate associations between health related behaviours and social class. Men and women aged over 14 years. Barcelona 1992

\begin{tabular}{|c|c|c|c|c|c|c|c|}
\hline & Sex & $\begin{array}{l}\text { Class I } \\
\text { OR }\end{array}$ & $\begin{array}{l}\text { Class II } \\
\text { OR }(95 \% \text { CI })\end{array}$ & $\begin{array}{l}\text { Class III } \\
\text { OR }(95 \% \text { CI })\end{array}$ & $\begin{array}{l}\text { Class IVa } \\
\text { OR }(95 \% \text { CI })\end{array}$ & $\begin{array}{l}\text { Class IVb } \\
\text { OR }(95 \% \text { CI })\end{array}$ & $\begin{array}{l}\text { Class V } \\
\text { OR }(95 \% \text { CI) }\end{array}$ \\
\hline \multicolumn{8}{|l|}{ Tobacco consumption } \\
\hline \multirow[t]{2}{*}{ Smoker $^{(1)}$} & $M$ & 1 & $0.71(0.49,1.01)$ & $0.93(0.67,1.28)$ & $1.15(0.83,1.57)$ & $1.44(0.97,2.13)$ & $1.31(0.74,2.32)$ \\
\hline & $\mathrm{F}$ & 1 & $0.74(0.47,1.16)$ & $0.67(0.44,1.02)$ & $0.60(0.40,0.92)$ & $0.79(0.48,1.32)$ & $0.36(0.19,0.67)$ \\
\hline \multicolumn{8}{|l|}{ Smoking cessation ${ }^{(2)}$} \\
\hline & $\mathrm{F}$ & 1 & $2.16(0.90,5.16)$ & $2.05(0.89,4.74)$ & $1.63(0.69,3.86)$ & $0.86(0.28,2.62)$ & $1.41(0.38,5.13)$ \\
\hline \multicolumn{8}{|l|}{ Alcohol consumption } \\
\hline \multirow[t]{2}{*}{ Non-drinker ${ }^{(3)}$} & $M$ & 1 & $1.14(0.77,1.68)$ & $1.13(0.80,1.61)$ & $1.18(0.83,1.66)$ & $1.32(0.86,2.01)$ & $1.68(0.93,3.04)$ \\
\hline & $\mathrm{F}$ & 1 & $1.04(0.70,1.54)$ & $1.03(0.71,1.48)$ & $1.66(1.16,2.38)$ & $2.27(1.47,3.51)$ & $2.92(1.84,4.62)$ \\
\hline \multirow[t]{2}{*}{ Light drinker ${ }^{(4)}$} & M & 1 & $0.91(0.64,1.30)$ & $1.02(0.74,1.40)$ & $0.81(0.60,1.12)$ & $0.77(0.52,1.14)$ & $0.57(0.32,1.00)$ \\
\hline & $\mathrm{F}$ & 1 & $0.95(0.64,1.40)$ & $1.19(0.83,1.71)$ & $0.71(0.49,1.01)$ & $0.55(0.35,0.86)$ & $0.45(0.28,0.72)$ \\
\hline \multirow[t]{2}{*}{$\begin{array}{l}\text { Excessive alcohol } \\
\text { consumption }^{(5)}\end{array}$} & M & 1 & $0.94(0.54,1.63)$ & $0.71(0.42,1.20)$ & $1.16(0.71,1.87)$ & $1.04(0.57,1.89)$ & $1.24(0.54,2.82)$ \\
\hline & $\mathrm{F}$ & 1 & $0.91(0.46,1.77)$ & $0.46(0.23,0.91)$ & $0.52(0.27,0.99)$ & $0.37(0.15,0.88)$ & $0.25(0.09,0.67)$ \\
\hline \multicolumn{8}{|l|}{ Usual physical activity } \\
\hline \multirow[t]{2}{*}{ Intense ${ }^{(6)}$} & $\mathrm{M}$ & 1 & $1.39(0.60,3.22)$ & $1.37(0.63,2.95)$ & $6.84(3.42,13.67)$ & $5.56(2.60,11.89)$ & $2.52(0.79,8.03)$ \\
\hline & $\mathrm{F}$ & 1 & $1.51(0.58,3.87)$ & $0.75(0.28,1.98)$ & $1.46(0.58,3.62)$ & $3.02(1.15,7.94)$ & $2.70(1.00,7.30)$ \\
\hline \multirow[t]{2}{*}{ Light-none ${ }^{(7)}$} & $\mathrm{M}$ & 1 & $0.91(0.64,1.28)$ & $0.66(0.48,0.91)$ & $0.55(0.40,0.75)$ & $0.47(0.32,0.70)$ & $1.25(0.71,2.20)$ \\
\hline & $\mathrm{F}$ & 1 & $0.79(0.54,1.17)$ & $0.90(0.63,1.30)$ & $0.93(0.65,1.32)$ & $0.68(0.44,1.05)$ & $0.65(0.41,1.01)$ \\
\hline \multicolumn{8}{|c|}{ Undertake no leisure time physical activity ${ }^{(8)}$} \\
\hline & M & 1 & $0.97(0.64,1.45)$ & $1.11(0.76,1.60)$ & $1.11(0.76,1.59)$ & $1.40(0.88,2.22)$ & $1.25(0.61,2.57)$ \\
\hline & $\mathrm{F}$ & 1 & $0.59(0.35,0.97)$ & $0.89(0.55,1.43)$ & $0.80(0.50,1.28)$ & $0.89(0.49,1.58)$ & $1.08(0.57,2.05)$ \\
\hline \multicolumn{8}{|c|}{ Two or more health behaviours ${ }^{(9)}$} \\
\hline & M & 1 & $0.74(0.51,1.08)$ & $0.93(0.67,1.29)$ & $1.26(0.91,1.73)$ & $1.50(1.01,2.22)$ & $1.46(0.82,2.58)$ \\
\hline & $\mathrm{F}$ & 1 & $0.81(0.52,1.27)$ & $0.70(0.46,1.06)$ & $0.71(0.46,1.07)$ & $0.88(0.53,1.46)$ & $0.33(0.18,0.62)$ \\
\hline
\end{tabular}

OR: odds ratio adjusted for age, employment status and family structure. ${ }^{(1)}$ Dependent variable: 1 smoker, 0 occasional smoker, non-smoker. ${ }^{(2)}$ Dependent variable: 1 ex-smoker, 0: smoker. ${ }^{(3)}$ Dependent variable: 1 non-drinker, 0 drinker. ${ }^{(4)}$ Dependent variable: 1 light drinker, 0 other. ${ }^{(5)}$ Dependent variable: 1 heavy drinker $($ over $40 \mathrm{~g} /$ day in men, over $20 \mathrm{~g}$ /day in women), 0 other drinkers and non-drinkers. ${ }^{(6)}$ Dependent variable: 1 intense physical activity, 0 other cases. ${ }^{(7)}$ Dependent variable: 1 light-none physical activity, 0 other cases. ${ }^{(8)}$ Dependent variable: 1 no leisure time physical activity, 0 yes. ${ }^{(9)}$ Dependent variable: 1 two or more health behaviours, 0 none or one.

Table 4 Percentage of people who present a number of health damaging behaviours (smokers, heavy drinkers or people who performed no leisure time physical activity) by social class. Age standardised percentages. Men and women aged over 14 years. Barcelona 1992

\begin{tabular}{|c|c|c|c|c|c|c|c|}
\hline $\begin{array}{l}\text { Number of } \\
\text { behaviours }\end{array}$ & Sex & $\begin{array}{l}\text { Class I } \\
\% \star(95 \% \text { CI })\end{array}$ & $\begin{array}{l}\text { Class II } \\
\% \%^{\star}(95 \% \text { CI })\end{array}$ & $\begin{array}{l}\text { Class III } \\
\% \star(95 \% \text { CI })\end{array}$ & $\begin{array}{l}\text { Class IVa } \\
\% \%^{\star}(95 \% \text { CI })\end{array}$ & $\begin{array}{l}\text { Class IVb } \\
\% *(95 \% \text { CI })\end{array}$ & $\begin{array}{l}\text { Class V } \\
\% \star(95 \% C I)\end{array}$ \\
\hline \multirow[t]{2}{*}{ None } & $M$ & $14.1(9.5,18.7)$ & $\begin{array}{l}15.0(10.2, \\
19.7)\end{array}$ & $13.1(9.8,16.4)$ & $12.6(9.4,15.7)$ & $9.4(5.2,13.6)$ & $13.1(1.8,24.4)$ \\
\hline & $\mathrm{F}$ & $9.1(4.0,14.1)$ & $13.8(9.3,18.3)$ & $10.2(7.3,13.0)$ & $12.7(9.9,15.5)$ & $11.3(6.6,16.1)$ & $7.8(2.7,12.9)$ \\
\hline \multirow[t]{2}{*}{ One } & M & $\begin{array}{l}48.6(39.8, \\
57.2)\end{array}$ & $\begin{array}{l}52.5(43.8, \\
61.2)\end{array}$ & $\begin{array}{l}51.0(44.3, \\
57.6)\end{array}$ & $\begin{array}{l}44.8(39.0 \\
50.5)\end{array}$ & $\begin{array}{l}43.0(33.5, \\
52.5)\end{array}$ & $\begin{array}{l}42.2(25.5 \\
58.8)\end{array}$ \\
\hline & $\mathrm{F}$ & $\begin{array}{l}63.2(48.5, \\
77.8)\end{array}$ & $\begin{array}{l}61.3(51.7, \\
71.0)\end{array}$ & $\begin{array}{l}67.3(59.5, \\
75.0)\end{array}$ & $\begin{array}{l}65.0(58.7, \\
71.1)\end{array}$ & $\begin{array}{l}63.0(51.9, \\
74.0)\end{array}$ & $\begin{array}{l}78.2(64.3 \text {, } \\
92.2)\end{array}$ \\
\hline \multirow[t]{2}{*}{ Two or more } & M & $\begin{array}{l}37.3(29.6, \\
44.9)\end{array}$ & $\begin{array}{l}32.4(25.4, \\
39.3)\end{array}$ & $\begin{array}{l}35.9 \text { (30.3, } \\
41.3)\end{array}$ & $\begin{array}{l}42.6(36.9, \\
48.3)\end{array}$ & $\begin{array}{l}47.5(37.6, \\
57.3)\end{array}$ & $\begin{array}{l}44.6(26.0, \\
63.1)\end{array}$ \\
\hline & $\mathrm{F}$ & $\begin{array}{l}27.6(19.1, \\
36.1)\end{array}$ & $\begin{array}{l}24.8(19.5, \\
30.0)\end{array}$ & $\begin{array}{l}22.5(18.5, \\
26.4)\end{array}$ & $\begin{array}{l}22.3(18.3, \\
26.2)\end{array}$ & $\begin{array}{l}25.6(18.5, \\
32.6)\end{array}$ & $13.9(6.7,20.9)$ \\
\hline
\end{tabular}

$\star \%$ : age standardised percentage.

multivariate analysis the association was not statistically significant (OR for class V: 1.25 , $95 \%$ CI: $0.61,2.57)$. In women there was no clear trend (tables 2 and 3 ).

Table 4 depicts the number of reported health risk behaviours according to social class. Women of higher classes were engaged in two or more health risk behaviours more frequently and it was statistically significant in multivariate analysis (OR for class V: 0.33, 95\% CI: 0.18, 0.62 ) (table 3). In men the situation is reversed, although it was not statistically significant in multivariate analysis (tables 3 and 4).

\section{Discussion}

This is one of the first studies on social inequalities in health related behaviours in a southern European city. Overall, it has shown that the patterns of tobacco consumption according to social class are different for men and women. In this regard, a higher prevalence of smokers was found among women of higher class. The opposite is true in men although not statistically significant. Smoking cessation was greater among men in the higher classes. Men and women of social class I and II were more likely to report light alcohol consumption. Excessive alcohol consumption among men showed no significant differences between classes; while among women the consumption was higher in the highest social classes. The lower class population, especially men, stated that they performed more usual physical activity and less leisure time physical activity (this was not statistically significant in multivariate analysis).

\section{TOBACCO CONSUMPTION}

In Spain tobacco is easily available and cheap, and its consumption has a high social acceptance. ${ }^{29}$ The highly addictive nature of tobacco products makes it very difficult to untangle the precise role of its social influences. For instance, it is clear that social pressure plays a key part in smoking adoption $^{30}$; nevertheless when these influences disappear or are recognised, a powerful addiction has been established. At this new stage, social influences may still play an important 
part, reinforcing the behaviour and some of its cognitive determinants. ${ }^{31}$ The modern epidemic of smoking consumption, can be seen as an example of the diffusion in a given society of an "innovation" 32 that would grow first among men, reaching its peak after 30-40 years. After this peak there would be a decrease, related to public awareness of the consequences of tobacco use, which would start to be visible after that time, especially regarding cancer. The epidemic among women would come later, ${ }^{33}{ }^{34}$ and would not eventually reach the same peak, because of the "vicarious" effects of tobacco use seen in men. ${ }^{4}$ Therefore, the epidemic of smoking would reflect the importance of social influences, especially of social position, as those groups who were the first to smokebecause of the "social" prestige of the innovation-are a few decades afterwards the first to quit, because of awareness of its consequences. This hypothesis is supported by many studies in European ${ }^{35}$ and other developed countries like the United States, Australia and Canada that report a higher prevalence of smokers among lower social classes and among those with lower education levels. ${ }^{153637}$ In contrast, in southern European countries, including Spain, the differences between social classes are not so marked among men; while women in higher classes smoke the most ${ }^{69353839}$ although smoking among women of lower classes has been increasing in recent years. ${ }^{7}$ In addition, it is noteworthy that smoking cessation rate (percentage of ex-smokers in relation to the total number of smokers and ex-smokers) is higher in groups with highest levels of education and in upper social classes in developed countries. ${ }^{40}{ }^{41}$ Our findings are consistent with this pattern, as we found higher rates of smoking cessation among upper social classes mainly in men.

\section{ALCOHOL CONSUMPTION}

Spain is among the top 10 countries of the world in the production of alcoholic beverages, particularly wine. Consumption of wine in small amounts has long been part of everyday meals and is socially accepted. In addition, initiation to alcoholic drinks usually takes place within the family, in the context of social events and family celebrations. ${ }^{42}$ Alcoholic beverages are cheap and widely available, which facilitates an increased consumption, although binge drinking (drinking fast for the sole purpose of getting drunk) is less common than in northern European countries. ${ }^{43}$ The most common pattern of consumption for the adult population is daily drinking, with the youngest population increasing their consumption at weekends. ${ }^{44}{ }^{45}$ The type of beverage consumed is mainly wine, although the pattern is changing to beer. ${ }^{46} 47$

In this study, men of upper classes were lighter drinkers, while among women, the higher classes declared greater consumption (both light and heavy drinkers). In a study done in the UK it was found that the prevalence of heavy drinkers among men is higher among manual workers, while the higher classes had more light and nondrinkers. In the case of women it was always the higher classes who drank more. ${ }^{2}$ This pattern has also been reported for Spain by social class in men $^{9}$ and by educational level in men and women. ${ }^{48}$ However, other studies have found no association between alcohol consumption and social class ${ }^{49}$ or have found an association showing that people of higher social class drink more. ${ }^{50}$ One study in the north of Europe has detected a change in the excessive alcohol consumption by social class: in the 1960 s or 1970 s non-manual workers drank more, a pattern that reversed during the 1980s. ${ }^{51}$ To explain this pattern, a model of diffusion of new habits by social class or educational level has been used. New habits, in this case alcohol consumption, are initiated by upper social classes or by the more educated as it was in relation to tobacco consumption. ${ }^{32}$ Hupkens et al have described that people with higher education levels consume the new beverage type more often and in greater numbers compared with people of lower educational level. This pattern is maintained in both northern and southern European countries. These differences in the consumption of new alcoholic beverages indicate a diffusion of new habits initiated by the more educated people. Furthermore, differences in consumption between men and women are smaller among those with higher education levels than among those with lower, which could be explained because of the consumption of new beverages in higher education levels. ${ }^{52}$

PHYSICAL ACTIVITY

Leisure time physical activity is not one of the most important activities that Spanish people do in their spare time, although they consider that physical activity is important for good health and recreation and it is an easy activity. ${ }^{53}$ Nevertheless, a decrease has been recently observed in the proportion of people who are inactive in leisure time. ${ }^{9}$

The pattern of physical activity found among men in Barcelona, where people in higher classes undertake more leisure time physical activity (although not statistically significant), but less usual physical activity, has been previously described. ${ }^{34-56}$ In the UK it has been reported, using data from two health surveys, that higher classes perform more leisure time physical activity. ${ }^{2}$ Salonen et al describe how, in two Finnish cohorts participating in a health related project in North Karelia, education level was positively related with leisure time physical activity, and negatively with occupational physical activity. ${ }^{57}$ Ford et al give similar results using data from a telephone survey carried out in Pittsburgh to determine physical activity in higher and lower socioeconomic status populations. ${ }^{58}$

In fact, usual physical activity is mainly related to occupational physical activity among workers, and to activities of daily living among people that do not have a paid employment (for example, houseworkers). Hence it is reasonable 
to expect that persons in lower social classes perform more intense physical activity as this is implicit in their occupations. ${ }^{59}$ Even so, it should be pointed out that the proportions of people performing intense physical activity are relatively low in all social classes, because in industrialised societies jobs require less and less physical activity. As a result, physical activity is becoming more and more part of leisure time. ${ }^{60}$

\section{LIMITATIONS AND CONCLUSION}

The possible limitations of information as declared in a health interview survey should be mentioned. The validity of declarations about alcohol consumption is unknown, although there are some reports suggesting that consumption is usually under-declared. ${ }^{43}{ }^{61}$ In fact the potential biases affecting this study would arise if the declarations were differential depending on social class, something that has not been studied in this country. We do not, however, have any evidence that supports this hypothesis.

Social class was derived from current or last occupation of the interviewed, although $44 \%$ of women and $22 \%$ of men were classified with the occupation of the head of the household (housewives, unemployed, students, etc). In this regard it should be mentioned that the results were very similar when all people had assigned the social class of the head of the household.

It is also necessary to mention that the sample size was insufficient to find statistically significant associations in some cases (for example leisure time physical activity in men), but standardised percentages and OR indicate the main trends.

This study found that the group whose health related behaviours imply greatest risk is lower class men. Women in more disadvantaged social situations smoke less and drink less alcohol. These results suggest that health policies should take into account these patterns. Conflicts of interest: none.

1 Blaxter M. Health and lifestyles. London: Routledge, 1990.

Townsend P, Davidson N, Whitehead M. Inequalities in health: The Black Report and The Health Divide. London Penguin Books, 1988

3 Dishman RK, Sallis JF, Orenstein DR. The determinants of physical activity and exercise. Public Health Rep 1985;100 $158-72$.

4 Lopez AD, Collishaw EN, Piha T. A descriptive model of the cigarette epidemic in developed countries. Tobacco Control 1994;3:242-7.

5 Pierce JP. International comparisons of trends in cigarette smoking prevalence. Am 7 Public Health 1989;79:152-7.

6 Graham I. Smoking prevalence among women in the European Community 1950-1990. Soc Sci Med 1996;43:24354.

7 Nebot M, Borrell C, Ballestín M, et al. JR. Prevalencia y características asociadas al consumo de tabaco en población general en Barcelona entre 1983 y 1992. Rev Clín Esp 1996;196:359-64

8 Regidor E, Gutiérrez-Fisac JL, Rodríguez C. Diferencias y desigualdades en salud en España. Madrid: Díaz de Santos, 1994.

9 Navarro V, Benach J y la Comisión científica de estudios de las desigualdades sociales en salud en España. Desigualdades sociales en salud en España. Madrid: Ministerio de Sanidad y Consumo y The School of Hygiene and Public Health, The Johns Hopkins University, 1996.

10 Borrell C, Pasarín MI. The study of social inequalities in health in Spain. Where are we? $f$ Epidemiol Community Health 1999;53:388-9.

11 Kunst AE, Groenhof F, Mackenbach JP and the EU Working Group on Socioeconomic Inequalities in Health. Occupational class and cause specific mortality in middle aged men in 11 European countries: comparison of population based studies. BMF 1998;16:1636-42.
12 Arias A, Rebagliato M, Palumbo MA, et al. Desigualdade en salud en Barcelona y Valencia. Med Clín (Barc) en salud en B

13 Borrell C, Arias A. Socio-economic factors and mortality in urban settings: the case of Barcelona (Spain). $\mathcal{F}$ Epidemiol Community Health 1995;49:460-5.

14 Borrell C, Regidor R, Arias LC, et al. Inequalities in mortality according to educational level in two large southern european cities. Int $\mathcal{F}$ Epidemiol 1999;28:58-63.

15 Borrell C, Plasència A, Pasarín I, et al. Widening social inequalities in mortality: the case of a southern European city (Barcelona). F Epidemiol Community Health 1997;51: 659-67.

16 Borrell C, Arias A, Baranda L, et al. Manual de l'enquesta de salut de Barcelona. Barcelona: Ajuntament de Barcelona, 1992

17 Vilain C. The evaluation and monitoring of public action on tobacco. Copenhagen: WHO Regional Office for Europe (Smoke-free Europe 1988; Series, no 3).

18 Gobierno Vasco. Encuesta de salud de la Comunidad Autónoma Vasca. Serie Estadísticas y Documentos de Trabajo, no 14. Vitoria: Gobierno Vasco, 1988

19 Welsh Heart Health Survey 1985. Heartbeat Wales Technical Reports Number Two. Protocol and Questioannaire. Wales: Health promotion Authority for Wales, 1989.

20 Domingo A, Marcos J. Propuesta de un indicador de la "clase social" basado en la ocupación. Gac Sanit 1989;3: $320-6$.

21 Grupo de trabajo de la Sociedad Española de Epidemiología. La medición de la clase social en ciencias de la salud. Barcelona: SG Editores, 1995.

22 Borrell C. Evolució de les desigualtats socials en salut a la ciutat de Barcelona, 1983-92. [Doctoral dissertation]. Barcelona: Universitat Autònoma de Barcelona, 1995.

23 Arber S, Lahelma E. Women, paid employment and ill-health in Britain and Finland. Acta Sociologica 1993;36: $121-38$

24 Arber S. Comparing inequalities in women's and men's health. Britain in the 1990s. Soc Sci Med 1997;44:773-88. 25 Anderson P, Cremona A, Paton A, et al. The risk of alcohol. Addiction 1993;88:1493-508.

26 US Department of Health and Human Services. Physical Activity and Health: $A$ report of the Surgeon General. Atlanta, GA: US Department of Health and Human Services, Center for Disease Control and Prevention, National Center for Chronic Disease Prevention and Health Promotion, International Medical Publishing, 1996.

27 Breslow EN, Day EN. Rates and rate standardization. Statistical methods in cancer research. Volume II: The design and analysis of cohort studies. Lyon: International Agency For Research on Cancer, 1987.

28 Hosmer DW, Lemeshow S. Applied logistic regression. New York: John Wiley, 1989.

29 Tuya DM. Tabaco y adolescentes: más vale prevenir. Med Clin (Barc) 1993;100:497-500.

30 McAlister A, Perry C, Maccoby N. Adolescent smoking: onset and prevention. Pediatrics 1979;63:650-8.

31 Prochaska JO, DiClemente CC. Towards a comprehensive model of change. In: Miller W, Heather N, eds. Treating addictive behaviors. New York: Plenum Press, 1986

32 Rogers EM. Diffusion of innovations. New York: The Free Press, 1995.

33 Waldron I. Patterns and causes of gender differences in smoking. Soc Sci Med 1991;32:989-1005.

34 Amos A. Women and smoking. Br Med Bull 1996;52:74-89.

35 Cavelaars AEJM. Socio-economic differences in smoking in 12 European countries. In: Cavelaars AEJM. Cross-national comparisons of socio-economic differences in health indicators. [PhD thesis]. Rotterdam: Erasmus University, 1998: 103-8.

36 Mackenback JP. Socio-economic health differences in the Netherlands: a review of recent empirical findings. Soc Sci Metherlands: a review

37 Garfinkel L. Trends in cigarette smoking in the United States. Prev Med 1997;26:447-50

38 Hill C. Trends in tobacco use in Europe. 7 Natl Cancer Inst Monographs 1992;12:21-4

39 La Vechia C, Pagano R, Decarli A, et al. Smoking in Italy, 1990-1991. Tumori 1994;80:175-80.

40 Reek JV, Adriaanse H. Cigarette smoking cessation rates by level of education in five western countries. Int 7 Epidemiol 1988;17:474-5.

41 Fernández E, Carné J, Schiaffino A, et al. El abandono del hábito tabáquico en Cataluña. Gac Sanit 1999;13:353-60.

42 Ariza C, Nebot M. Factores asociados al consumo de tabaco en una muestra de escolares de enseñanza primaria y ecundaria. Gac Sanit 1995;9:101-9.

43 Gutiérrez-Fisac JL. Indicadores de consumo de alcohol en España. Med Clín (Barc) 1995;104:544-50.

44 Alvarez FJ, Queipo D, Rio C, et al. Patterns of alcohol consumption among the general population of Castille and Leon (Spain). Alcohol Alcohol 1993;28:43-54

45 Villalbí JR, Nebot M, Ballestín M. Los adolescentes ante las sustancias adictivas: tabaco, alcohol y drogas no institucionalizadas. Med Clin (Barc) 1995;104:784-8.

46 Edwards G, Anderson P, Babor TF, et al. Alcohol policy and public good. Oxford: Oxford University Press, 1994.

47 Alvarez FJ, del Rio MC. Alcohol and alcoholism in Spain. Alcologia 1992;4:259-66.

48 Regidor E, Gutiérrez-Fisac JL, Rodríguez C, et al. Las desigualdades sociales y la salud en España. In: Navarro C, Cabasés JM, Tormo MJ. La salud y el sistema sanitario en España. Informe SESPAS 1995. Barcelona: SG Editores, 1995:19-44. 
49 Dunbar GC, Morgan DDV. The changing pattern of alcohol consumption in England and Wales 1978-85. BMF (10

50 Rice N, Carr-Hill R, Dixon P, et al. The influence of households on drinking behaviour: a multilevel analysis. Soc Sci Med 1998;46:971-9.

51 Romelsjö A, Lundberg M. The changes in the social class distribution of moderate and high alcohol consumption and of alcohol-related disabilities over time in Stockolm County and in Sweden. Addiction 1996;91:1307-23. 52 Hupkens CLH, Knibbe RA, Drop MJ. Alcohol consump-
tion in the European Community: uniformity and diversity in drinking patterns. Addiction 1993;88:1391-404.

53 Vázquez B. Actitudes y prácticas deportivas de las mujeres españolas. Madrid: Instituto de la Mujer, 1993.

54 Stephens T, Jacobs DR, White CC. A descriptive epidemiology of leisure-time physical activity. Public Health Rep ogy of leisure-time physical activity. Public Health Rep
1985;100:147-58.

55 Pomerleau J, Pederson LL, Ostbye $\mathrm{T}$, et al. Health behaviours and socio-economic status in Ontario, Canada. Eur F Epidemiol 1997;13:613-22.
56 Iribarren C, Luepker RV, McGovern PG, et al. Twelve-year trends in cardiovascular disease risk factors in the Minessota Heart Survey. Arch Intern Med 1997;157:873-81.

57 Salonen JT, Slater JS, Tuomilehto J, et al. Leisure time and occupational physical activity: risk of death from ischemic heart disease. Am f Epidemiol 1988;127:87-94.

58 Ford ES, Merritt RK, Heath GW, et al. Physical activity behaviors in lower and higher socioeconomic status populations. Am $\mathcal{7}$ Epidemiol 1991;133:1246-56.

59 Domínguez-Berión MF, Borrell $\mathrm{C}$, Nebot $\mathrm{M}$, et al. Actividad física habitual de la población residente en la ciudad de Barcelona. Gac Sanit 1998;12:100-9.

60 Pate RR, Prat M, Blair SN, et al. Physical activity and public health: a recomendation from the Centers for Disease Control and Prevention and the American College of Sports Medicine. FAMA 1995;273: 402-7.

61 Hellerstedt WL, Jeffery RW, Murray DM. The association between alcohol intake and adiposity in the general population. Am f Epidemiol 1990; 132:595-611. 